\title{
Impaired LH surge amplitude in gonadotrope- specific progesterone receptor knockout mice
}

\author{
Chirine Toufaily1,*, Gauthier Schang,,*, Xiang Zhou', Philipp Wartenberg², Ulrich Boehm², John P Lydon ${ }^{3}$, \\ Ferdinand Roelfsema ${ }^{4}$ and Daniel J Bernard1 \\ 1Department of Pharmacology and Therapeutics, McGill University, Montréal, Québec, Canada \\ 2Department of Experimental Pharmacology, Center for Molecular Signaling, Saarland University School of Medicine, Homburg, Germany \\ ${ }^{3}$ Department of Molecular and Cellular Biology, Baylor College of Medicine, Houston, Texas, USA \\ ${ }^{4}$ Department of Internal Medicine, Section Endocrinology and Metabolic Diseases, Leiden University Medical Center, Leiden, The Netherlands
}

Correspondence should be addressed to D J Bernard: daniel.bernard@mcgill.ca

*(C Toufaily and G Schang contributed equally to this work)

\begin{abstract}
The progesterone receptor (PR, encoded by Pgr) plays essential roles in reproduction. Female mice lacking the PR are infertile, due to the loss of the protein's functions in the brain, ovary, and uterus. PR is also expressed in pituitary gonadotrope cells, but its specific role therein has not been assessed in vivo. We therefore generated gonadotropespecific Pgr conditional knockout mice (cKO) using the Cre-LoxP system. Overall, both female and male cKO mice appeared phenotypically normal. cKO females displayed regular estrous cycles (vaginal cytology) and normal fertility (litter size and frequency). Reproductive organ weights were comparable between wild-type and cKO mice of both sexes, as were production and secretion of the gonadotropins, $\mathrm{LH}$ and FSH, with one exception. On the afternoon of proestrus, the amplitude of the LH surge was blunted in cKO females relative to controls. Contrary to predictions of earlier models, this did not appear to derive from impaired GnRH self-priming. Collectively, these data indicate that PR function in gonadotropes may be limited to regulation of $\mathrm{LH}$ surge amplitude in female mice via a currently unknown mechanism.
\end{abstract}

\section{Introduction}

The progesterone receptor (PR, product of the Pgr gene) plays fundamental and pleiotropic roles in the control of reproduction. This is perhaps most clearly demonstrated in female Pgr-knockout mice, which are infertile because of impairments in LH surges from the pituitary, LH-induced meiotic maturation and ovarian follicle rupture, uterine decidualization, and sexual behavior (Lydon et al. 1995, Chappell et al. 1999). The LH surge is driven by ovarian estrogens, which have positive feedback effects at both the hypothalamic and pituitary levels. In the hypothalamus, estrogens stimulate expression of kisspeptin (Kiss1) in neurons of the anteroventral periventricular nucleus (AVPV); kisspeptin, in turn, stimulates GnRH release (Messager et al. 2005, d'Anglemont de Tassigny et al. 2008). In the pituitary, high levels of estrogens increase the sensitivity of gonadotrope cells to $\mathrm{GnRH}$, amplifying $\mathrm{LH}$ release (Lasley et al. 1975, Dafopoulos et al. 2004). Estrogens stimulate PR expression in multiple cell types, and PRs in kisspeptin neurons play essential roles in estrogen-positive feedback. Indeed, estradiol-induced LH surges, ovulation (as reflected by corpora lutea numbers), and fertility (e.g., litter size) are impaired in female mice with conditional 
deletion of Pgr in kisspeptin neurons (Stephens et al. 2015, Gal et al. 2016). Though kisspeptin expression appears to be normal in the AVPV of these animals, the data indicate that LH surges in mice depend, at least in part, on intact PR function in kisspeptin neurons.

These results do not, however, rule out an additional role for the PR in estrogen-positive feedback and LH surge generation at the pituitary level. Estrogens induce PR expression in gonadotropes and PR has been suggested to modulate GnRH action (i.e., self-priming) therein (Turgeon \& Waring 1994, Aguilar et al. 2003). GnRH self-priming is a phenomenon in which prior GnRH pulses potentiate the actions of subsequent GnRH pulses on LH release (Waring \& Turgeon 1980, Higuchi \& Kawakami 1982). Self-priming, which is more pronounced in rats than mice, is estrogen and protein-synthesis dependent, but does not require increases in GnRH receptor numbers (Pickering \& Fink 1976, Colin et al. 1996). Rather, GnRH actions appear to be enhanced in a cAMP- and PR-dependent manner (Turgeon \& Waring 1994, Abdilnour \& Bourne 1995). For example, GnRH selfpriming is reduced, though not completely eliminated, in estradiol-treated pituitary cultures of Pgr-knockout mice (Turgeon \& Waring 2001). Similarly, GnRH self-priming is blocked in ovariectomized, estradiol-treated Pgr-knockout mice in vivo (Chappell et al. 1999). Nevertheless, the necessity for PR function in gonadotropes for gonadotropin production, LH surge dynamics, and fertility have not been assessed. To address these gaps in knowledge, we generated gonadotrope-specific Pgr-knockout mice.

\section{Materials and methods}

\section{Animals}

The $P g r^{f x} / f x$ and GnrhrlRES-Cre/IRES-Cre (GRIC) mice were described previously (Wen et al. 2008, Fernandez-Valdivia et al. 2010). $P g r^{f \times / f x}$ males were crossed with GRIC females

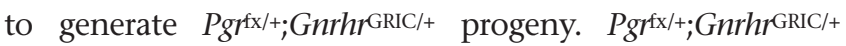
females were then crossed to $P g_{\mathrm{r} x / \mathrm{fx}}$ males to generate $P g r^{f \times / f x} ; G n r h r^{+/+}$controls and $P g r^{f x / f x} ; G n r h r^{G R I C /+}$ conditional knockouts (cKOs). In order to purify gonadotropes by fluorescence-activated cell sorting (FACS), we crossed $P g r^{f \times / f x}$ animals with $G t(R O S A 26)^{A C T B-t d T o m a t o-E G F P ~ m i c e ~}$ (mTmG/mTmG, stock 007676 from Jackson Laboratories) to generate $P g^{f \mathrm{fx} / \mathrm{fx}} ; R_{0}$ osa $26^{\mathrm{mTmG} / \mathrm{mTmG}}$ males, which were then crossed to $P g r^{\mathrm{fx} /}+; G n r h r_{\mathrm{GRIC} /+}$ females to generate $P g r^{\mathrm{fx} / \mathrm{fx}} ; G n r h r^{\mathrm{GRIC} /+} ; R^{2}$ osa26 $6^{\mathrm{mTmG} /+}$ males and females. Controls for FACS were generated by crossing Rosa $26^{\mathrm{mTmG} / \mathrm{mTmG} \text { and }}$

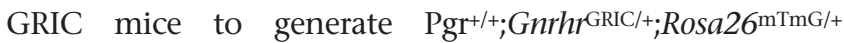
progeny. Genotyping and assessment of genomic recombination were conducted as previously described (Zhou et al. 2016) (primers listed in Table 1). All animal experiments were performed in accordance with institutional and federal guidelines and were approved by the McGill University and Goodman Cancer Centre Facility Animal Care Committee (Protocol 5204).

\section{Fluorescence-activated cell sorting of gonadotropes}

FACS was performed at the Cell Vision Core Facility for Flow Cytometry and Single Cell Analysis of the Life Science Complex at the Rosalind and Morris Goodman Cancer Research Centre at McGill University. Pituitary cell dispersion and cell sorting were performed as previously described (Ho et al. 2011, Li et al. 2017). Here, EGFPpositive (gonadotropes) and tdTomato-positive (nongonadotropes) cells were sorted from control and cKO animals. On average, $1.2 \times 10^{4}$ EGFP-positive and $2.5 \times 10^{5}$ tdTomato-positive cells were obtained from each group (ten mice per group).

\section{Assessment of female puberty onset, estrous cyclicity, and fertility}

Females were monitored daily after weaning (postnatal day 21 ) to determine the onset of vaginal opening. At 6 weeks of age, estrous cyclicity was assessed by daily vaginal swabs for 3 weeks. Vaginal cells were smeared on glass slides and stained with $0.1 \%$ methylene blue to identify cycle stages (Caligioni 2009). The number of days spent in each stage (proestrus, estrus, or diestrus/metestrus) was then counted and divided by the total number of days to determine the relative proportion of time spent in each stage. At 9 weeks of age, a group of females $(n=6$ per genotype) were mated with wild-type age-matched C57BL/6 males (Charles River) for 6 months. Breeding cages were monitored daily, and the date of birth and number of pups were recorded.

\section{Reproductive organ collection}

Testes, seminal vesicles, ovaries, and uteri were dissected from 10-week-old control and cKO males and females. Females were killed at $07: 00 \mathrm{~h}$ on the morning of estrus. All organs were weighed on a precision balance.

\section{Blood collection}

Blood was collected from 10-week-old control and cKO males and females $(07: 00 \mathrm{~h}$ on estrus morning) by cardiac 
Table 1 Primer sequences.

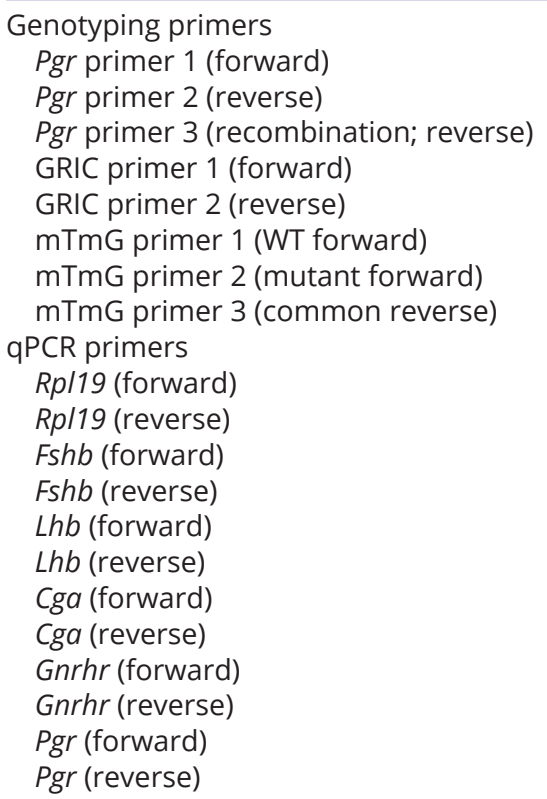

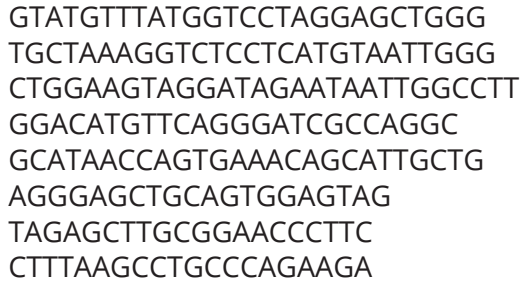

puncture, allowed to clot for $30 \mathrm{~min}$ at room temperature, and spun down at $850 \boldsymbol{g}$ for $10 \mathrm{~min}$ to collect serum. Sera were stored at $-20^{\circ} \mathrm{C}$ until assayed for $\mathrm{LH}$ and FSH. To assess LH pulsatility in males, four microliters of blood were collected from the tail tip, every 10 min over $4 \mathrm{~h}$, starting $2 \mathrm{~h}$ before lights off. To assess LH surge amplitude in females, four blood samples (four microliters each) were collected from the tail tip over 10 consecutive days: at 10:00 $\mathrm{h}$ and at 18:00, 19:00 and 20:00 h (light cycle on/off at 07:00h/19:00h). For all tail tip blood collections, the animals were acclimatized to the procedure by massaging the tail for 2 weeks prior to the start of the blood collection. All tail tip blood samples were immediately diluted (1:30) in $1 \times$ PBS containing $0.05 \%$ of Tween, gently vortexed, and placed on dry ice. Blood dilutions were stored at $-80^{\circ} \mathrm{C}$ until LH ELISAs were performed.

In the LH surge experiment, we compared the maximal LH level obtained from each animal on proestrus afternoon (peak). In females surging more than once over the 10-day sampling period, an average of the maximal value was calculated and used in the analysis. With the sampling method used, we may have missed the true peak of the LH surge. Nevertheless, it enabled us to observe one or more surges in all animals, which would not have been the case if we relied exclusively on vaginal smears for staging proestrus. Moreover, the same approach was used for all animals, and the pattern of results was comparable between the two genotypes.

\section{Hormone analyses}

Serum FSH levels were assessed by a Milliplex kit (Millipore, MPTMAG-49K, custom-made for FSH only) following the manufacturer's instructions (minimal detection limit: $9.5 \mathrm{pg} / \mathrm{mL}$; intra-assay CV <15\%). Serum and whole blood LH levels were measured using an in-house sandwich ELISA as previously described in Steyn et al. (2013), Czieselsky et al. (2016), Li et al. (2017) (detection limit: 0.117 to $30 \mathrm{ng} / \mathrm{mL}$; an intra-assay $\mathrm{CV}<10 \%$ ). As we reported previously (and as seen here), LH levels are higher in serum than whole blood samples (Li et al. 2018b).

\section{Reverse transcription and quantitative-PCR}

Pituitary glands were dissected from control and cKO animals (10 weeks old; females were killed at 07:00 h on estrous morning), snap-frozen in liquid nitrogen, and stored at $-80^{\circ} \mathrm{C}$. Pituitaries were homogenized in TRIzol reagent (15596018, ThermoFisher Scientific), and total RNA was extracted following the manufacturer's guidelines. For cells from the FACS experiments, total RNA was extracted using a Total RNA Mini Kit (Geneaid, RB300, New Taipei City, Taiwan). Reverse transcription was performed as previously described (Turgeon et al. 2017) using Moloney murine leukemia virus reverse transcriptase (0000172807, Promega) and random hexamers (0000184865, Promega). qPCR was run on a Corbett Rotorgene 600 instrument (Corbett Life Science) using EvaGreen qPCR Mastermix 
(ABMMmix-S-XL; Diamed, Mississauga, ON, Canada) and the primers are listed in Table 1. Expression levels of genes of interest were determined using the $2^{-\Delta \Delta \mathrm{Ct}}$ method (Livak \& Schmittgen 2001) and ribosomal protein L19 (Rpl19) for normalization. All primers were validated for efficiency and specificity.

\section{GnRH self-priming}

The protocol to examine GnRH self-priming was adapted from Chappell et al. (1999), with some modifications based on Higuchi \& Kawakami (1982). Indeed, changes were required because we were unsuccessful in reliably and consistently observing GnRH self-priming in wild-type mice using the protocol described in Chappell et al. (1999). We developed a reliable and reproducible self-priming method after several rounds of optimization. Females ( 7 to 9 weeks of age) were ovariectomized in accordance with standard operating procedure 206 of the McGill University and Goodman Cancer Centre Facility Animal Care Committee. Briefly, an incision was made at the midline of the middorsum of the animal. On each side of the animal, a small incision was made in the muscle above the ovary, and the ovary pulled out of the body cavity with forceps. The tissue was then cauterized at the level of the oviduct and the ovary was removed. All incisions were closed by sutures. One week following ovariectomy, each female was given a s.c. injection of $2 \mu \mathrm{g}$ estradiol benzoate (EB, E8515, SigmaAldrich) dissolved in sesame oil $(100 \mu \mathrm{L}$ of a $0.02 \mu \mathrm{g} / \mu \mathrm{L}$ solution) between 09:30 and 10:00h. At 07:00 h on the next day, blood from the tail tip was collected as described above. Each female was then given six consecutive s.c. injections of $50 \mathrm{ng}$ GnRH (L8008, Sigma-Aldrich) $(100 \mu \mathrm{L}$ of a $0.5 \mathrm{ng} / \mu \mathrm{L}$ solution) at 1 -h intervals. Blood from the tail tip was collected 10 min after each GnRH administration. To minimize stress associated with frequent sampling and injections, mice were handled daily for 2 weeks prior to the onset of injections. Blood samples were diluted and frozen as described above. Samples were then stored at $-80^{\circ} \mathrm{C}$ until LH ELISAs were performed.

\section{Immunofluorescence}

GRIC mice were crossed to eR26- $\tau$ GFP mice (Wen et al. 2011) to produce animals in which Cre-expressing cells are tagged with $\tau$ GFP (GRIC/eR26- $\tau$ GFP). Eight week-old animals were transcardially perfused with $4 \%$ paraformaldehyde (158127 Sigma-Aldrich) in $0.1 \mathrm{M}$ PBS (P3813, Sigma-Aldrich) under ketamine/xylazine (7005294 and 10124950, Serumwerk Bernburg, Bernburg,
Germany) anesthesia. Brains were removed, soaked in fixative for $2 \mathrm{~h}$ and 18\% sucrose overnight, and then frozen in optimal cutting temperature (OCT) (14020108926, Leica). Serial $14-\mu \mathrm{m}$ coronal cryosections were thaw mounted onto SuperFrost Plus slides (10149870 Thermo Fisher). Brain sections were blocked in 0.1 M PBS, $0.3 \%$ Triton X-100, 10\% donkey serum (017-000-121, Jackson ImmunoResearch) and 3\% BSA (A2153, Sigma-Aldrich) and incubated with chicken anti-GFP (1:1000, A10262, Thermo Fisher) and rabbit anti-kisspeptin (1:500, AB9754, Millipore) overnight at $4^{\circ} \mathrm{C}$, followed by goat antichicken 488 (1:500, A11039, Thermo Fischer, Waltham, Massachusetts, USA) and biotinylated donkey anti-rabbit (1:500, BA-1000, Vector Laboratory, Burlingame, CA, USA) and streptavidin CY5 (1:500, 016-170-084, Jackson ImmunoResearch Inc). For nuclear staining, sections were incubated with $5 \mu \mathrm{g} / \mathrm{mL}$ Hoechst 33258 dye (14530, Sigma-Aldrich) in 0.1 M PBS for 5 min and mounted with Fluoromount-G (0100-01, Southern Biotech, Birmingham, Alabama, USA). Sections were analyzed on an Imager.M2 microscope equipped with AxioVision software (Zeiss).

\section{Statistical analysis}

All data were analyzed on GraphPad Prism 6 using Student t-tests. Results were considered statistically significant when $P<0.05$. For LH pulses, data were deconvoluted using MatLab (Veldhuis et al. 2016) and number of pulses were compared between genotypes using Student $t$-test. Comparisons between the two groups of mice challenged with GnRH were done with the GLM procedure for repeated measurements. Calculations were performed with Systat 13 (Systat Software, Inc, San Jose, CA, USA).

\section{Results}

\section{Generation of progesterone receptor conditional knockout mice}

To address the role of the PR in gonadotropes, we generated gonadotrope-specific Pgr-knockout (cKO) mice by crossing floxed $P g r(P g r \mathrm{fx} / \mathrm{fx})$ and GRIC mice (GnrhrGRIC/GRIC). First, we verified $P g r$ recombination in different tissues from controls and cKOs of both sexes. As expected, recombination was restricted to the pituitary of both females and males, and to the testes and epididymides of males (Fig. 1A). Next, we quantified the efficiency and specificity of $\mathrm{Pgr}$ recombination by assessing the level of $\mathrm{Pgr}$ mRNA expression in purified gonadotropes (Cre-recombinase expressing cells, EGFP-positive) compared to other cell 

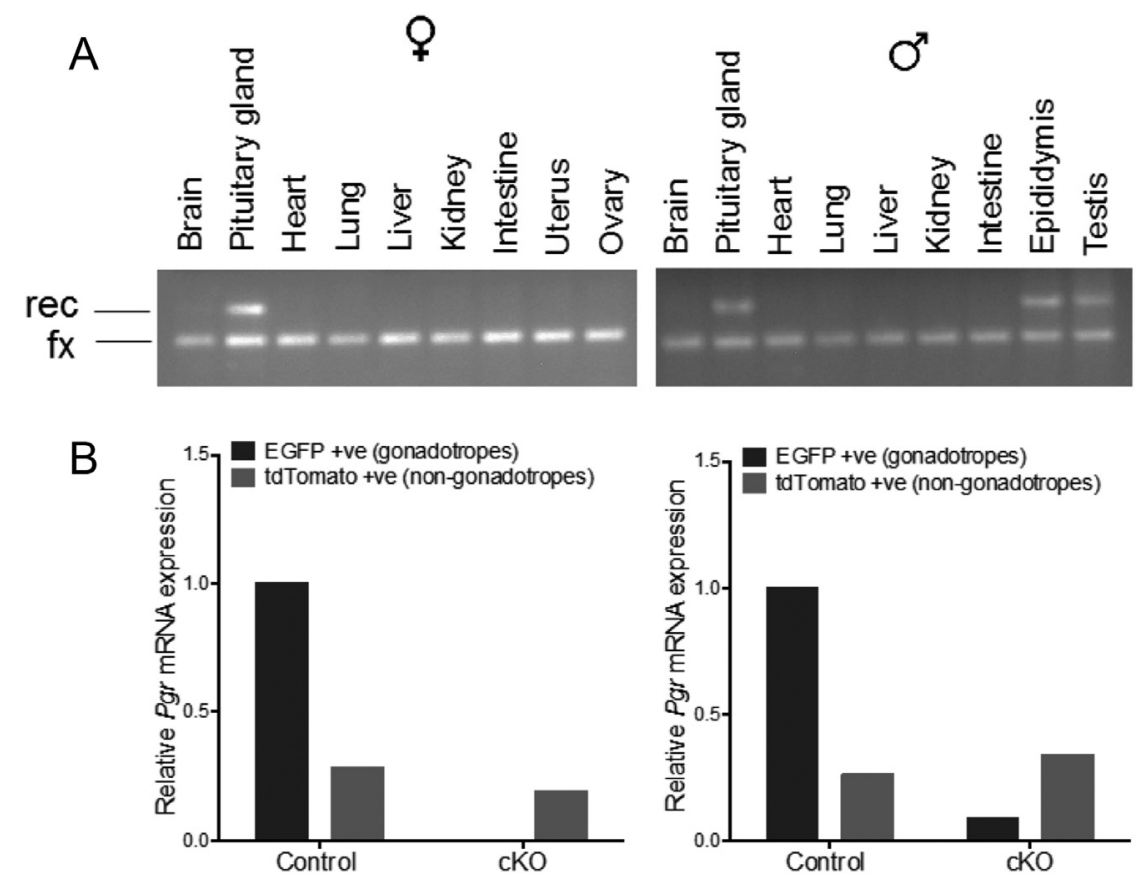

\section{Figure 1}

Pgr recombination efficiency and specificity in gonadotrope cells. (A) PCR of genomic DNA from different tissues shows the specificity of recombination in the pituitary glands of female (left) and male cKOs (right), as well as in the epididymis and testis in males (right). rec: recombined; fx: floxed. (B) Quantitative-PCR of cDNA from control (Pgrr/+;Rosa26 $\mathrm{mTmG} /+;^{+}$GnrhrGRIC/+) and CKO (Pgrff/fx; Rosa26 $6^{\mathrm{mTmG} /+; G n r h r G R I C /+}$ ) mice, showing Pgr expression in purified gonadotrope (EGFP +ve, black) versus non-gonadotrope (tdTomato +ve, gray) cells, in females (left) and males (right).

populations in the pituitary (Cre-negative, tdTomatopositive). In both male and female cKOs, Pgr expression was markedly reduced in gonadotropes (Fig. 1B, green bars). Pgr expression in non-gonadotropes (lactotropes) was intact (Fig. 1B, red bars). Recent single-cell RNA-seq data confirm that $P g r$ expression is enriched in gonadotropes and lactotropes in murine pituitaries (Cheung et al. 2018).

\section{Normal fertility and gonadal development in Pgr cKO mice}

cKO females and their control littermates reached puberty at similar ages, as assessed by vaginal opening (Fig. 2A). We did not measure the day of first estrus, which is considered by some to be a more robust measure of puberty onset
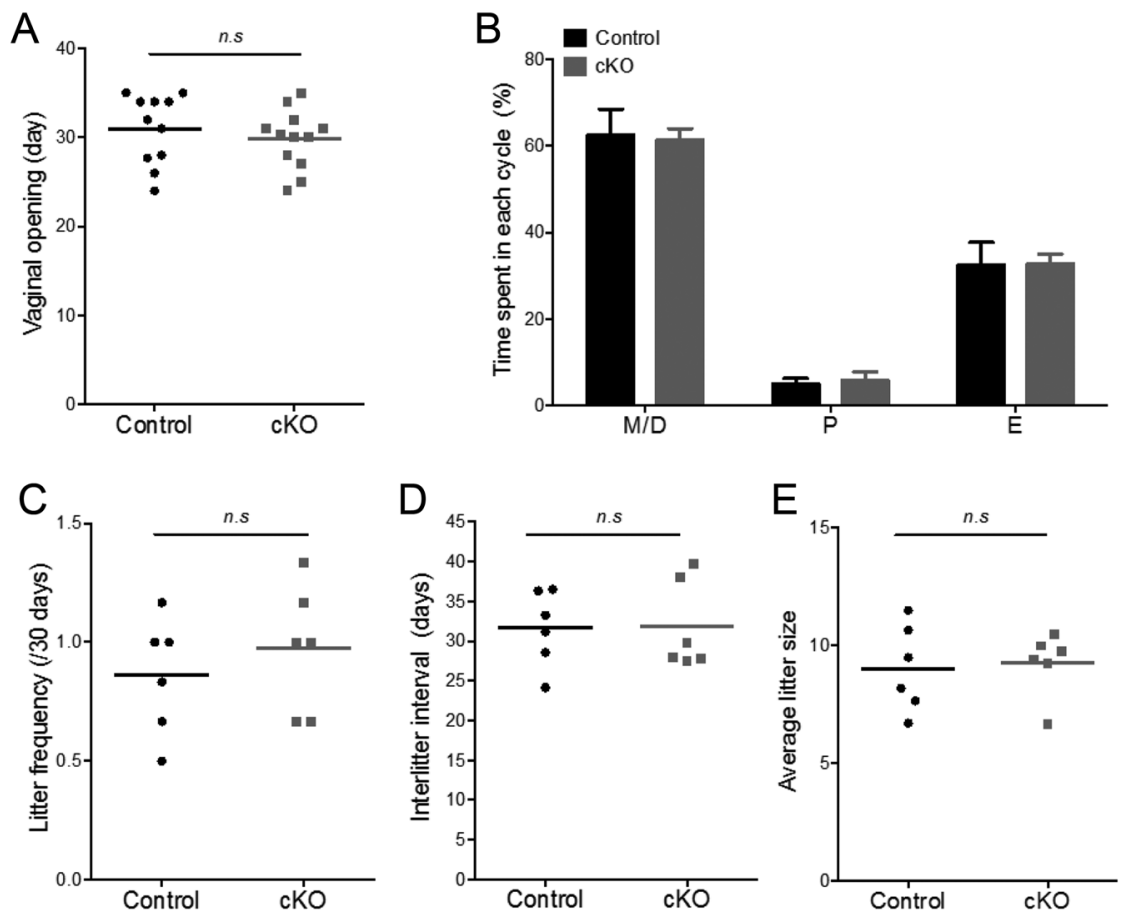

\section{Figure 2}

Pgr expression in gonadotropes is not essential for normal reproductive function in female mice. (A) Age of vaginal opening (days) in female control (black) and cKO mice (gray). (B) Percentage of time spent in each stage of the estrous cycle in control and CKO females. (C, D and E) Fertility in control and CKO females. (C) Frequency of delivery per 30 days, (D) inter-litter interval (days), and (E) average litter size for each mouse ( $n=6$ per genotype). Two samples Student $t$-test was performed for statistical analysis. n.s, non-significant; M/D, metestrus/diestrus; $\mathrm{P}$, proestrus; and $\mathrm{E}$, estrus. 
A
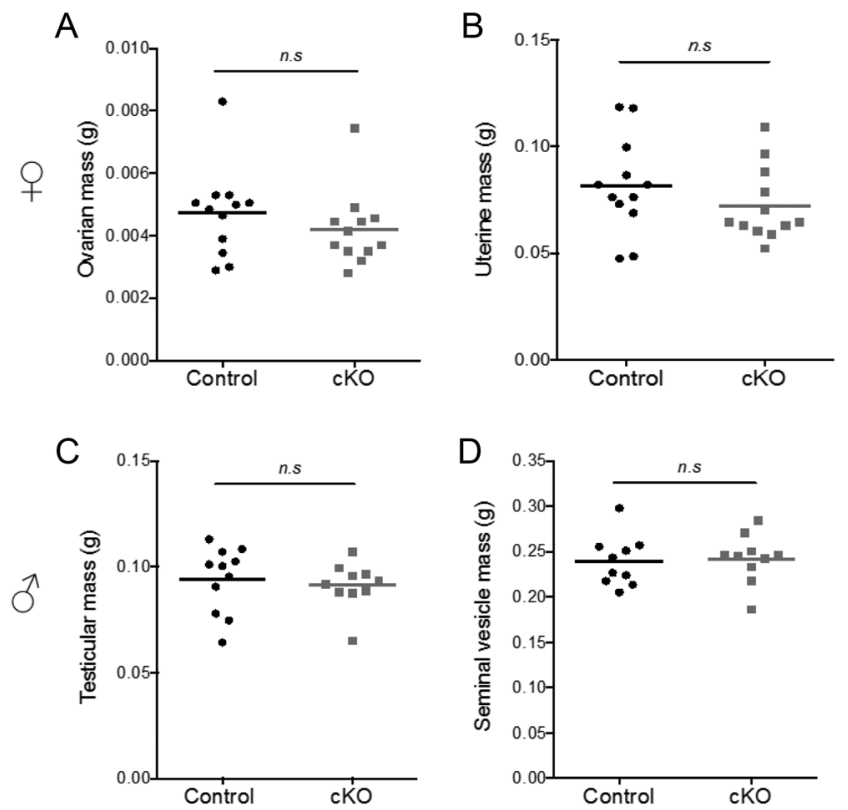

Figure 3

Normal reproductive organ weights in female and male Pgr CKO mice. (A) Ovarian and (B) uterine mass in 10-week-old control and cKO females $(n=12)$. (C) Testicular and (D) seminal vesicle mass in 10-week-old control and $\mathrm{CKO}$ males $(n=10)$. Student $t$-tests were performed for statistical analysis. n.s, non-significant.

than vaginal opening. However, the other phenotypes in these mice (or lack thereof) suggest that day of first estrus was unlikely to be affected. Pgr cKO females had normal estrous cyclicity, as assessed by vaginal cytology (Fig. 2B). In breeding trials, frequency of delivery, inter-litter interval, and average litter size were comparable between control and cKO females (Fig. 2C, D and E). Ovarian and uterine masses were also normal in cKO females (Fig. 3A and $\mathrm{B}$ ). In males, testicular and seminal vesicle masses were equivalent between genotypes (Fig. 3C and D).

\section{FSH and LH production is intact in Pgr CKO mice}

Although fertility and gonadal development were apparently unaffected in the absence of gonadotrope PR function, we measured serum LH and FSH levels in both females and males. Blood samples were collected from control and cKO females on the morning of estrus, just after lights on. Serum FSH (Fig. 4A and B) and LH levels (Fig. 4C and D) were equivalent between genotypes. Similarly, pituitary expression of the gonadotropin subunit genes (Fshb, Lhb, and Cga) and the GnRH receptor (Gnrhr, Fig. 5) did not differ between control and cKO mice, with two exceptions (Fig. 5F and H). Cga mRNA levels were reduced and Gnrhr mRNA levels increased in cKO males relative to controls. The variation in serum FSH and pituitary Fshb

(C) 2020 Society for Endocrinology Published by Bioscientifica Ltd.
Printed in Great Britain
mRNA levels is likely explained by the fact that some females were still in the midst of the secondary surge, while others were not at the time of sampling.

\section{Pulsatile LH secretion is normal in Pgr cKO males}

While there were no apparent effects of PR loss on LH production, we next examined LH pulse frequency. We focused on males, as LH pulsatility varies markedly across the estrous cycle in females (Czieselsky et al. 2016). There were no genotype-dependent differences in LH pulse amplitude or frequency (Fig. 6 and Table 2).

\section{Female Pgr cKO mice have blunted preovulatory LH surges}

We assessed the role of PR in gonadotropes on the LH surge. Profiles of the LH surge in controls (left) and cKOs (right) are shown in Fig. 7A and B, respectively. The number of surges detected across the 10-day sampling period appeared to be reduced in cKO females, but this was not statistically significant (Fig. 7C). Next, we compared the amplitude of the LH surge between controls and cKOs.
A
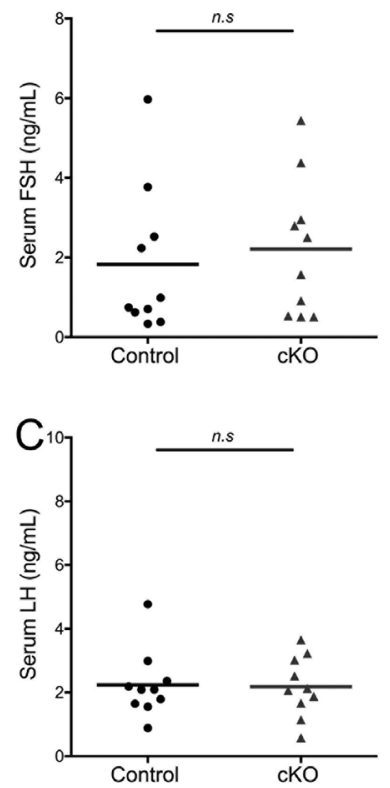

B

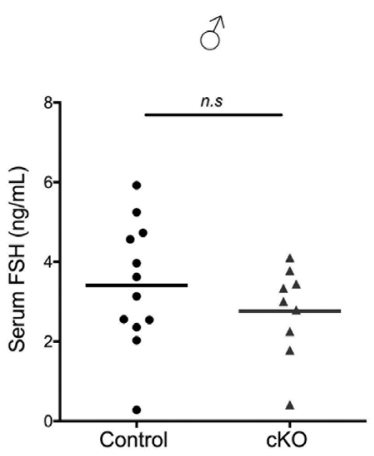

D

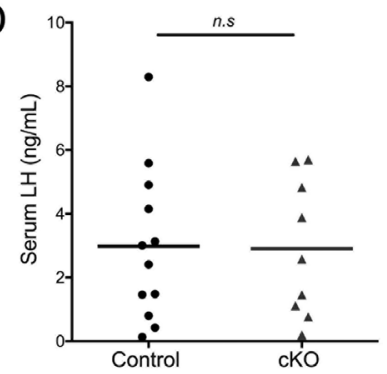

Figure 4

Intact serum gonadotropin levels in both female and male Pgr cKO mice. (A and B) Serum FSH and (C and D) LH levels in 10-week-old control and cKO females ( $n=10$ per genotype, left panels) and males ( $n=12$ controls and $n=9 \mathrm{cKO}$, right panels). Female samples were collected at 07:00 h on estrous morning. Student $t$-tests were performed for statistical analysis. n.s., non-significant. 

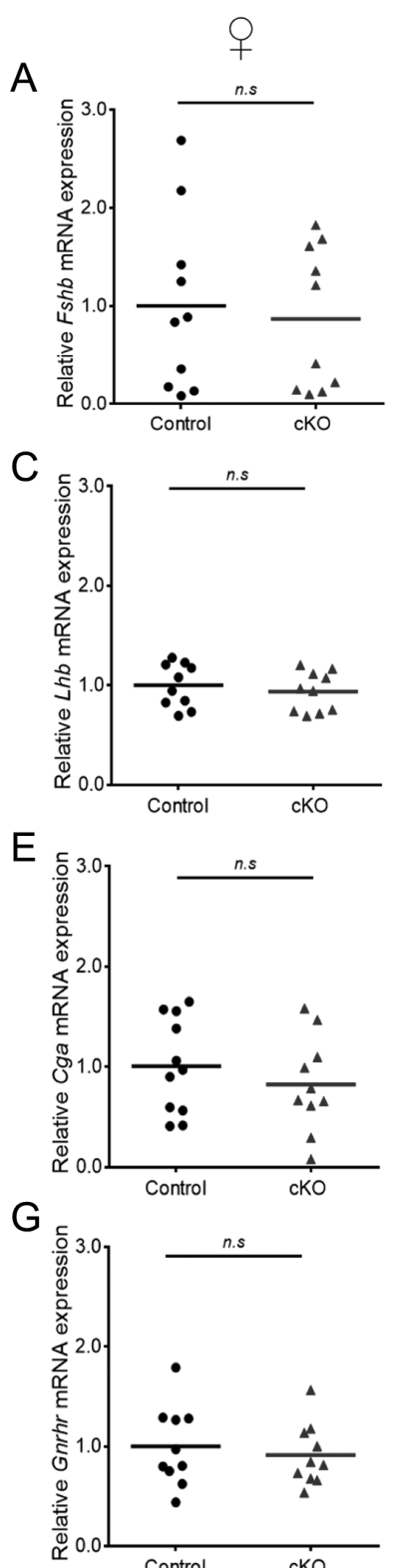

B
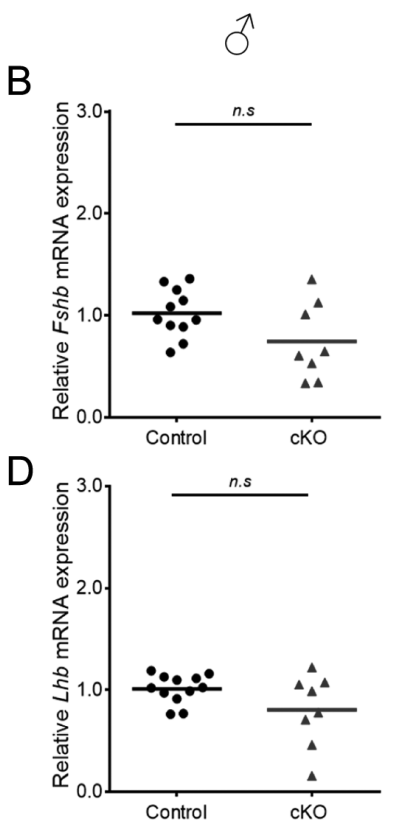

$\mathrm{F}$

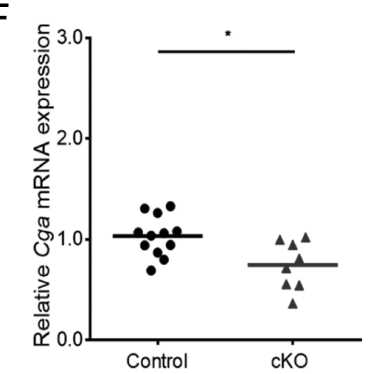

$\mathrm{H}$

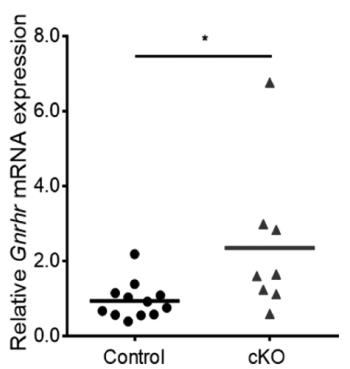

Figure 5

No differences in the expression of pituitary gonadotropin subunits in Pgr cKO mice. (A and B) FSH $\beta$-subunit (Fshb), (C and D) LH $\beta$-subunit (Lhb), (E and F) common $\alpha$-subunit ( $\mathrm{Cga}$ ), and ( $\mathrm{G}$ and $\mathrm{H}$ ) GnRH receptor (Gnrhr) mRNA levels in 10-week-old control and cKO females $(n=10$ per genotype, left panels) and males ( $n=12$ controls and $n=8 \mathrm{cKO}$, right panels). Female samples were collected at 07:00 h on estrous morning. Student $t$-tests were performed for statistical analysis. ${ }^{*} P<0.05$, n.s, non-significant.

Consistent with data from the morning of estrus (Fig. 4C), there was no genotype difference in LH levels on the morning of proestrus. Although most of the mice surged during the 10-day period (Fig. 7A, B and C), the maximal LH levels measured during the surge were significantly lower in cKO relative to control females (Fig. 7D).

\section{Female Pgr cKO mice do not display impaired GnRH self-priming}

Finally, based on previous reports (Waring \& Turgeon 1992, Turgeon \& Waring 1994, 2001, Chappell et al. 1999, Aguilar et al. 2003, Attardi et al. 2007), we assessed the effects of gonadotrope-specific PR loss on GnRH selfpriming as a potential mechanism underlying reduced LH surge amplitude in these animals. Mean serum LH levels before the first GnRH injection and 10 min after each injection (six injections in total) are shown in Fig. 8. The amplitude of GnRH-stimulated LH release increased following successive GnRH injections, indicating that self-priming occurred in both genotypes. Blood LH concentrations increased after GnRH administration (ANOVA: $P<0.0001$ ), but there was no difference between genotypes $(P=0.90)$ and no interaction between time and genotype $(P=0.70)$. There was a highly significant difference in LH increase between the first and subsequent GnRH injections, and the second and the fourth and following administrations ( $P$ values between 0.0001 and 0.012), but thereafter this effect leveled off.

\section{Discussion}

We generated conditional Pgr-knockout mice to assess PR function in pituitary gonadotrope cells. The data suggest that PR's primary role in this cell type is to regulate the amplitude of the LH surge in females. We did not observe any other alterations in reproductive physiology in either sex. As Pgr knockdown was highly efficient, the apparently normal gonadotropin synthesis and secretion in males and females (except on proestrus) is unlikely to derive from preservation of some PR function (i.e., incomplete recombination by Cre). Indeed, global Pgr-knockout mice similarly show normal LH and FSH production under most conditions (Chappell et al. 1997). Overall, our results confirm and extend some previous observations, while challenging other in vivo and in vitro findings.

Results from global Pgr-knockout mice suggest that the PR plays an important role in GnRH self-priming in gonadotropes (Chappell et al. 1999, Turgeon \& Waring 2001). Therefore, the most parsimonious explanation of the blunted LH surge in Pgr cKO mice would be impaired GnRH self-priming. However, we did not observe any such impairment, at least under the conditions used here. We attempted to employ the protocol described in Chappell et al. (1999), but the GnRH dose used previously ( 4 ng) was insufficient to stimulate LH release in our hands 
A
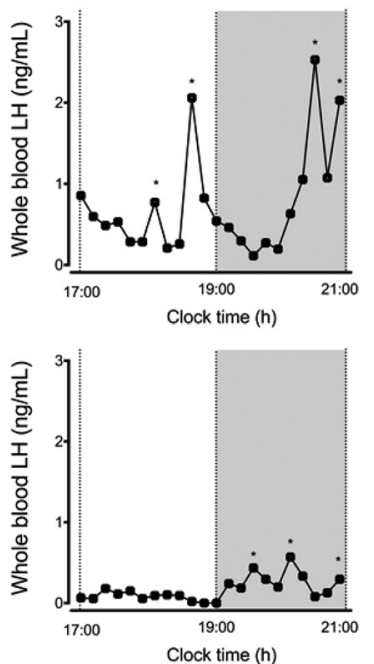
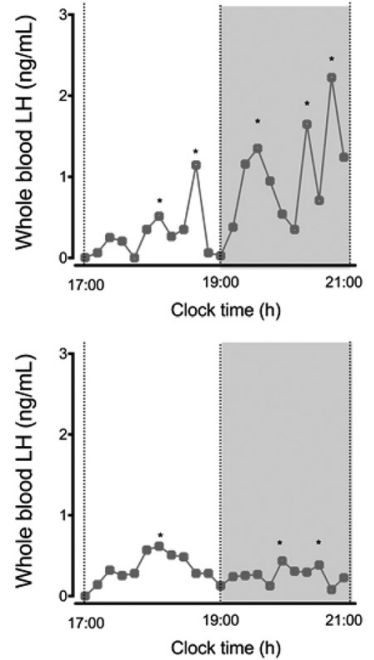

B

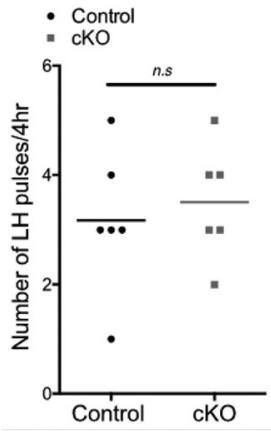

\section{Figure 6}

Normal LH pulses in CKO males. Blood samples were collected over $4 \mathrm{~h}$ at 10 -min intervals from either control $(n=7)$ and cKO $(n=6)$ males. (A) Representative profiles of $\mathrm{LH}$ secretion from two control (black graphs, left) and two cKO (gray graphs, right) males. The gray area represents the period of lights-off on a 07:00/19:00 h (on/off) light/dark cycle. Each asterisk (*) indicates a pulse. (B) Quantification of the number of LH pulses in the 4-h sampling period. Student $t$-tests were performed for statistical analysis. n.s, nonsignificant. (data not shown). We developed a new protocol based on a previous report in rats (Higuchi \& Kawakami 1982). Here, we modified the estrogen priming (no 17 $\beta$-estradiol implant added during the ovariectomy, and we increased the amount of EB to $2 \mu \mathrm{g}), \mathrm{GnRH}$ dose (50 $\mathrm{ng}$ per injection), and frequency of GnRH treatment (once per hour, for a total of six injections) relative to Chappell et al. (1999). We observed enhanced LH release with successive $\mathrm{GnRH}$ injections (indicative of self-priming), but there was no difference between genotypes. The data suggest that PR is not required for GnRH self-priming in murine gonadotropes and that PR regulates LH surge amplitude via a distinct mechanism in these cells.

It is also possible that reduced LH surge amplitude might be explained by effects originating outside of the gonadotrope. For example, Pgr cKO females could have reduced circulating estradiol levels relative to control. We did not assess this parameter as, in our experience, measurements of serum estradiol levels in mice are unreliable (Haisenleder et al. 2011, Fortin et al. 2014,
Li et al. 2017). However, as FSH and LH production, and ovary and litter sizes, are normal in $\mathrm{Pgr}$ cKO mice, there is no reason to suspect impairments in gonadotropinstimulated estradiol production. Alternatively, as Cre activity has been observed in some neurons of GRIC mice (Wen et al. 2010, Schauer et al. 2015), it is possible that the reduced LH surge amplitude might derive from loss of PR in the brain in addition to the pituitary. Indeed, PR expression in the AVPV is necessary for LH surge induction (Chappell \& Levine 2000). However, there is no Cre activity in either GnRH neurons (Wen et al. 2010) or kisspeptin neurons in the AVPV or arcuate nucleus (Fig. 9) of GRIC mice. In addition, female mice lacking PR in kisspeptin neurons show more dramatic reproductive deficits than what we observe here, including advanced onset of puberty, reduced fertility, and impaired ovulation (Stephens et al. 2015). We therefore conclude that it is unlikely that the phenotypes described in the Pgr cKO mice derive from loss of the PR in GnRH or kisspeptin neurons.

Table 2 Deconvolution analysis of circulating LH in six control and six KO mice sampled at 10-min intervals for $4 \mathrm{~h}$.

\begin{tabular}{|c|c|}
\hline & Control mice \\
\hline Burst number (\#/4 h) & $3.2 \pm 0.5$ \\
\hline Fast half-life (min) & 1.0 \\
\hline Slow half-life (min) & $5.5 \pm 1.1$ \\
\hline Mode (min) & $10.8 \pm 2.0$ \\
\hline Basal secretion (IU/mL) & $10.6 \pm 2.7$ \\
\hline Pulsatile secretion (IU/mL) & $8.8 \pm 2.9$ \\
\hline Total secretion (IU/mL) & $19.4 \pm 3.9$ \\
\hline Mean pulse mass (IU/mL) & $2.7 \pm 1.0$ \\
\hline
\end{tabular}

\begin{tabular}{c}
\hline KO mice \\
\hline $3.5 \pm 0.5$ \\
1.0 \\
$6.5 \pm 0.7$ \\
$11.3 \pm 2.1$ \\
$7.7 \pm 2.7$ \\
$10.8 \pm 4.1$ \\
$18.5 \pm 5.5$ \\
$3.1 \pm 1.2$ \\
\hline
\end{tabular}

\begin{tabular}{c}
\hline $\boldsymbol{P}$ value \\
\hline 0.64 \\
0.44 \\
0.84 \\
0.46 \\
0.70 \\
0.89 \\
0.78 \\
\hline
\end{tabular}

\begin{tabular}{c}
\hline $\boldsymbol{P}$ value (log-transformed data) \\
\hline 0.55 \\
0.36 \\
0.90 \\
0.54 \\
0.79 \\
0.69 \\
0.98 \\
\hline
\end{tabular}

Data are mean \pm S.E.M. Statistical comparisons were done with the Student's two-sided $t$-test for unpaired data.

https://joe.bioscientifica.com https://doi.org/10.1530/JOE-19-0013
(C) 2020 Society for Endocrinology Published by Bioscientifica Ltd. Printed in Great Britain 
A

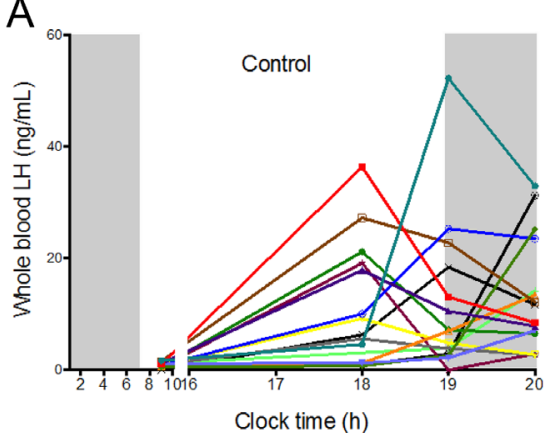

Clock time (h)

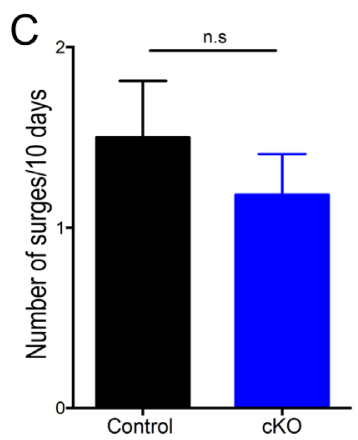

B

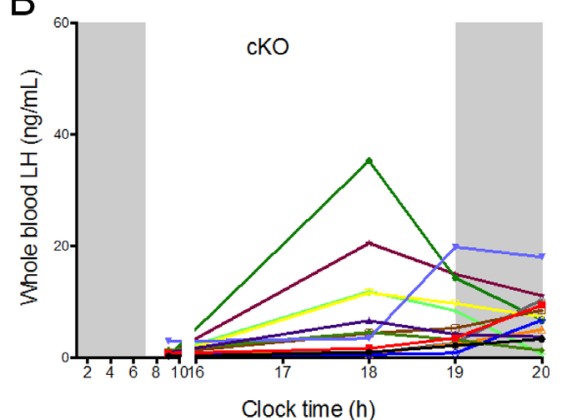

$\mathrm{D}$

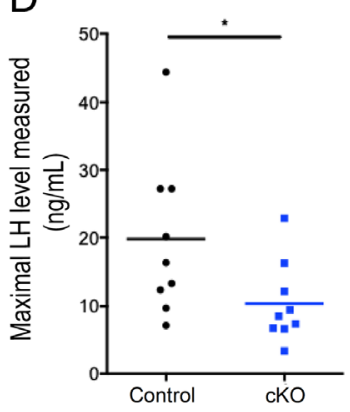

Figure 7

The LH surge is blunted in Pgr-knockout females. Blood samples were collected four times daily for 10 consecutive days. Representative profiles of the $\mathrm{LH}$ secretion obtained on proestrus from control (A) and cKO (B) female mice. Different colors indicate different mice. Gray areas represent the dark phase of the light/dark cycle. (C) Number of surges observed in each mouse during the 10 days of the experiment. (D) Maximal LH levels measured on proestrus from control $(n=9)$ and cKO $(n=9)$ females. Student $t$-tests were performed for statistical analysis. ${ }^{*} p<0.05$. n.s, non-significant. Note: maximal values in panel $D$ are lower than in panels $A$ and $B$ because averages were used in panel $D$ in mice that surged more than once (see 'Methods' section). A full colour version of this figure is available at https://doi.org/10.1530/JOE-19-0013.
Based on previous reports, we would have expected effects of PR deletion on FSH. Estradiol-treated premenopausal women show increased FSH production in response to exogenous progesterone administration (Hutchens et al. 2016). Also, pre-menopausal women co-treated with estradiol benzoate and progesterone produce more FSH in response to exogenous GnRH compared to women treated with estradiol benzoate alone (Lasley et al. 1975). In rodents, PR and progesterone also appear to stimulate FSH production. For example, progesterone and its analogs (e.g., R5020), both alone or in synergy with activin A, strongly stimulate the activity of murine Fshb promoter-reporters in immortalized murine gonadotrope cells, L $\beta$ T2 (Thackray et al. 2006, Thackray \& Mellon 2008). There was some suggestion that GnRH might stimulate Fshb mRNA expression in a PR-dependent fashion in these cells (An et al. 2009). In rats, the PR antagonists, RU486 and Org31710, attenuate the primary LH and FSH surges on proestrus, while blocking the secondary FSH surge on the morning of estrus (Knox \& Schwartz 1992, Knox et al. 1993, Roa et al. 2008a,b). Nevertheless, we did not detect the differences in serum FSH or pituitary Fshb mRNA levels between genotypes in either sex. One interpretation of these data is that we did not sample females at the appropriate cycle stage to observe effects of the gene deletion on FSH. Though we collected blood and pituitaries on the morning of estrus, it was a few hours after the peak of the secondary surge (Li et al. 2018a). Nonetheless, litter size is normal, arguing against an impairment in FSH production at any cycle stage. Although the data suggest that PR is dispensable for FSH production, it is important to consider that there may be functional redundancy in the system. Specifically, the related androgen and/or glucocorticoid receptors might compensate for the absence of PR in gonadotropes (Turgeon \& Waring 1999, McGillivray et al. 2007, Wu et al. 2014).

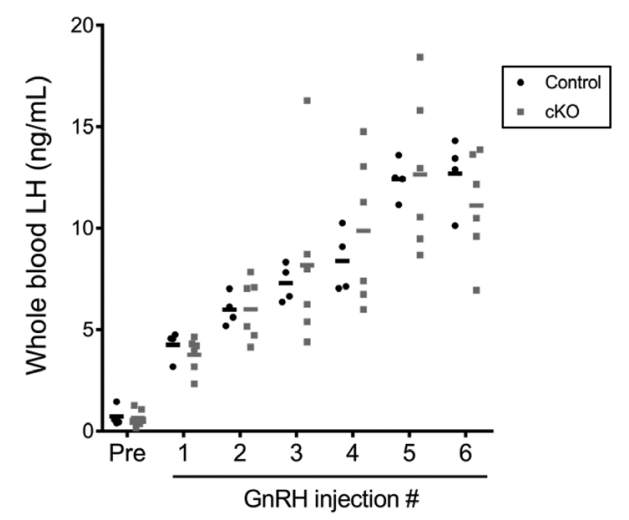

Figure 8

Control and cKO females show equivalent levels of GnRH self-priming. Blood samples were collected from ovariectomized, EB-injected females at 07:00 h. Females were then given six injections of GnRH ( $50 \mathrm{ng}$ per injection) at 1-h intervals. Blood samples were collected $10 \mathrm{~min}$ after each injection. Mean whole blood LH levels in control $(n=4)$ and cKO $(n=6)$ females are shown. GLM procedure for repeated measurements was used for statistical analysis. 


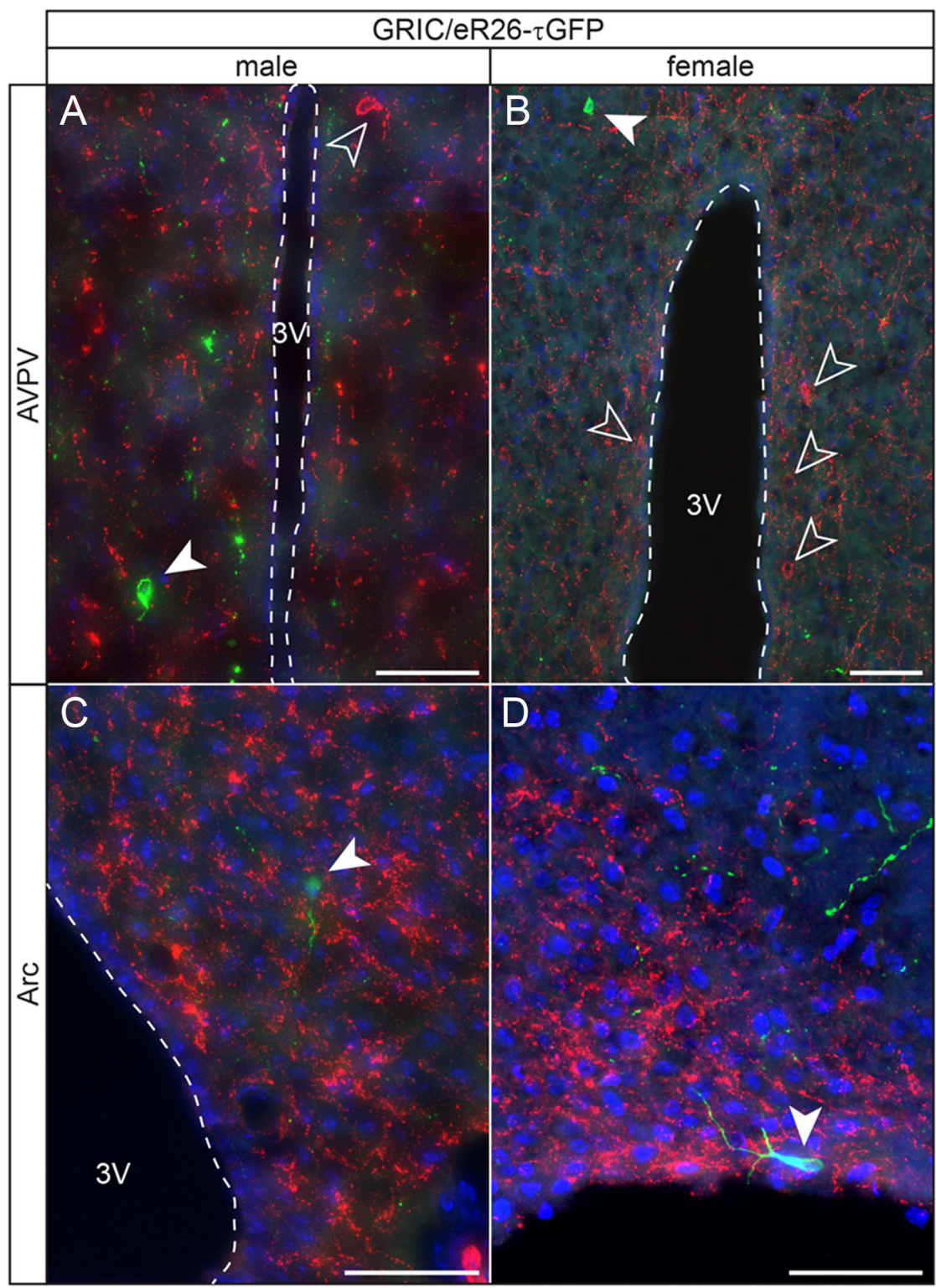

\section{Figure 9}

Kisspeptin neurons in the anteroventral periventricular nucleus (AVPV) and arcuate nucleus (ArC) do not express GnRHR. (A, B, C and D) Immunofluorescence staining for kisspeptin (red) in brain sections showing the AVPV (A and B) and the $\operatorname{Arc}(C$ and $D)$ from adult male and female GRIC/eR26- $\tau$ GFP mice. Note that GnRHR neurons (green, filled arrowheads) do not colocalize with kisspeptin neurons (empty arrowheads). Nuclei were stained with Hoechst 33258 (blue); Scalebars: $50 \mu \mathrm{m}$. 3V, third ventricle.
In summary, LH surge amplitude is reduced in gonadotrope-specific Pgr-knockout mice, but gonadotropin production and fertility are otherwise intact in these animals. The data suggest that progesteronenegative feedback at the level of the pituitary may be negligible, but that PR contributes to positive feedback effects of estrogens at this level of the HPG axis. Future studies should determine the mechanisms through which PR regulates LH surge amplitude as the receptor does not appear to play a necessary role in GnRH self-priming.

\section{Declaration of interest}

The authors declare that there is no conflict of interest that could be perceived as prejudicing the impartiality of the research reported.

\section{Funding}

This work was supported by the Canadian Institutes of Health Research (operating grants MOP-123447 and 133394 to D J B, and Doctoral Research Award 152308 to G S), the Natural Sciences and Engineering Research Council of Canada (2015-05178 to D J B), Fonds de Recherche du Québec Santé (fellowship number 31338 to G S), a Samuel Solomon Fellowship in Reproductive Endocrinology (to G S), Réseau Québecois en Reproduction (to C T), and Centre for Research in Reproduction and Development (to C T).

\section{References}

Abdilnour G \& Bourne GA 1995 Adenosine 3',5'-cyclic monophosphate and the self-priming effect of gonadotrophin-releasing hormone. Molecular and Cellular Endocrinology 107 1-7. (https://doi. org/10.1016/0303-7207(94)03418-s)

Aguilar R, Bellido C \& Sanchez-Criado JE 2003 The role of estrogendependent progesterone receptor in protein kinase C-mediated LH 
secretion and GnRH self-priming in rat anterior pituitary glands. Journal of Endocrinological Investigation 26 527-532. (https://doi. org/10.1007/BF03345215)

An BS, Poon SL, So WK, Hammond GL \& Leung PC 2009 Rapid effect of GNRH1 on follicle-stimulating hormone beta gene expression in LbetaT2 mouse pituitary cells requires the progesterone receptor. Biology of Reproduction 81 243-249. (https://doi.org/10.1095/ biolreprod.109.076216)

Attardi B, Scott R, Pfaff D \& Fink G 2007 Facilitation or inhibition of the oestradiol-induced gonadotrophin surge in the immature female rat by progesterone: effects on pituitary responsiveness to gonadotrophin-releasing hormone (GnRH), GnRH self-priming and pituitary mRNAs for the progesterone receptor A and B isoforms. Journal of Neuroendocrinology 19 988-1000. (https://doi.org/10.1111/ j.1365-2826.2007.01613.x)

Caligioni CS 2009 Assessing reproductive status/stages in mice. Current Protocols in Neuroscience 48 A.4I.1-A.4I.8. (https://doi. org/10.1002/0471142301.nsa04is48)

Chappell PE \& Levine JE 2000 Stimulation of gonadotropin-releasing hormone surges by estrogen. I. Role of hypothalamic progesterone receptors. Endocrinology 141 1477-1485. (https://doi.org/10.1210/ endo.141.4.7428)

Chappell PE, Lydon JP, Conneely OM, O'Malley BW \& Levine JE 1997 Endocrine defects in mice carrying a null mutation for the progesterone receptor gene. Endocrinology 138 4147-4152. (https:// doi.org/10.1210/endo.138.10.5456)

Chappell PE, Schneider JS, Kim P, Xu M, Lydon JP, O'Malley BW \& Levine JE 1999 Absence of gonadotropin surges and gonadotropinreleasing hormone self-priming in ovariectomized (OVX), estrogen (E2)-treated, progesterone receptor knockout (PRKO) mice. Endocrinology 140 3653-3658. (https://doi.org/10.1210/endo.140. 8.6895)

Cheung LYM, George AS, McGee SR, Daly AZ, Brinkmeier ML, Ellsworth BS \& Camper SA 2018 Single-cell RNA sequencing reveals novel markers of male pituitary stem cells and hormone-producing cell types. Endocrinology 159 3910-3924. (https://doi.org/10.1210/ en.2018-00750)

Colin IM, Bauer-Dantoin AC, Sundaresan S, Kopp P \& Jameson JL 1996 Sexually dimorphic transcriptional responses to gonadotropinreleasing hormone require chronic in vivo exposure to estradiol. Endocrinology 137 2300-2307. (https://doi.org/10.1210/endo.137. 6.8641179)

Czieselsky K, Prescott M, Porteous R, Campos P, Clarkson J, Steyn FJ, Campbell RE \& Herbison AE 2016 Pulse and surge profiles of luteinizing hormone secretion in the mouse. Endocrinology 157 4794-4802. (https://doi.org/10.1210/en.2016-1351)

Dafopoulos K, Kotsovassilis CG, Milingos S, Kallitsaris A, Galazios G, Zintzaras E, Sotiros P \& Messinis IE 2004 Changes in pituitary sensitivity to GnRH in estrogen-treated post-menopausal women: evidence that gonadotrophin surge attenuating factor plays a physiological role. Human Reproduction 19 1985-1992. (https://doi. org/10.1093/humrep/deh383)

d'Anglemont de Tassigny X, Fagg LA, Carlton MB \& Colledge WH 2008 Kisspeptin can stimulate gonadotropin-releasing hormone (GnRH) release by a direct action at GnRH nerve terminals. Endocrinology 149 3926-3932. (https://doi.org/10.1210/en.2007-1487)

Fernandez-Valdivia R, Jeong J, Mukherjee A, Soyal SM, Li J, Ying Y, Demayo FJ \& Lydon JP 2010 A mouse model to dissect progesterone signaling in the female reproductive tract and mammary gland. Genesis 48 106-113. (https://doi.org/10.1002/dvg.20586)

Fortin J, Boehm U, Deng CX, Treier M \& Bernard DJ 2014 Folliclestimulating hormone synthesis and fertility depend on SMAD4 and FOXL2. FASEB Journal 28 3396-3410. (https://doi.org/10.1096/fj. 14-249532)

Gal A, Lin PC, Cacioppo JA, Hannon PR, Mahoney MM, Wolfe A, Fernandez-Valdivia R, Lydon JP, Elias CF \& Ko C 2016 Loss of fertility in the absence of progesterone receptor expression in kisspeptin neurons of female mice. PLOS ONE 11 e0159534. (https://doi.org/ 10.1371/journal.pone.0159534)

Haisenleder DJ, Schoenfelder AH, Marcinko ES, Geddis LM \& Marshall JC 2011 Estimation of estradiol in mouse serum samples: evaluation of commercial estradiol immunoassays. Endocrinology 152 4443-4447. (https://doi.org/10.1210/en.2011-1501)

Higuchi T \& Kawakami M 1982 Luteinizing hormone responses to repeated injections of luteinizing hormone releasing hormone in the rat during the oestrous cycle and after ovariectomy with or without oestrogen treatment. Journal of Endocrinology 93 161-168. (https://doi.org/10.1677/joe.0.0930161)

Ho CC, Zhou X, Mishina Y \& Bernard DJ 2011 Mechanisms of bone morphogenetic protein 2 (BMP2) stimulated inhibitor of DNA binding 3 (Id3) transcription. Molecular and Cellular Endocrinology 332 242-252. (https://doi.org/10.1016/j.mce.2010.10.019)

Hutchens EG, Ramsey KA, Howard LC, Abshire MY, Patrie JT \& McCartney CR 2016 Progesterone has rapid positive feedback actions on LH release but fails to reduce LH pulse frequency within $12 \mathrm{~h}$ in estradiol-pretreated women. Physiological Reports 4 e12891. (https:// doi.org/10.14814/phy2.12891)

Knox KL \& Schwartz NB 1992 RU486 blocks the secondary surge of follicle-stimulating hormone in the rat without blocking the drop in serum inhibin. Biology of Reproduction 46 220-225. (https://doi.org/ 10.1095/biolreprod46.2.220)

Knox KL, Ringstrom SJ \& Schwartz NB 1993 RU486 blocks the effects of inhibin antiserum or luteinizing hormone on the secondary folliclestimulating hormone surge. Endocrinology 133 277-283. (https:// doi.org/10.1210/endo.133.1.8319576)

Lasley BL, Wang CF \& Yen SS 1975 The effects of estrogen and progesterone on the functional capacity of the gonadotrophs. Journal of Clinical Endocrinology and Metabolism 41 820-826. (https://doi. org $/ 10.1210 /$ jcem-41-5-820)

Li Y, Schang G, Boehm U, Deng CX, Graff J \& Bernard DJ 2017 SMAD3 regulates follicle-stimulating hormone synthesis by pituitary gonadotrope cells in vivo. Journal of Biological Chemistry 292 2301-2314. (https://doi.org/10.1074/jbc.M116.759167)

Li Y, Fortin J, Ongaro L, Zhou X, Boehm U, Schneyer A, Bernard DJ \& Lin HY 2018a Betaglycan (TGFBR3) functions as an inhibin A, but not inhibin B, coreceptor in pituitary gonadotrope cells in mice. Endocrinology 159 4077-4091. (https://doi.org/10.1210/en.2018-00770)

Li Y, Schang G, Wang Y, Zhou X, Levasseur A, Boyer A, Deng CX, Treier M, Boehm U, Boerboom D, et al. 2018b Conditional deletion of FOXL2 and SMAD4 in gonadotropes of adult mice causes isolated FSH deficiency. Endocrinology 159 2641-2655. (https://doi.org/10.1210/ en.2018-00100)

Livak KJ \& Schmittgen TD 2001 Analysis of relative gene expression data using real-time quantitative PCR and the 2(-Delta Delta C(T)) method. Methods 25 402-408. (https://doi.org/10.1006/meth.2001.1262)

Lydon JP, DeMayo FJ, Funk CR, Mani SK, Hughes AR, Montgomery Jr CA, Shyamala G, Conneely OM \& O'Malley BW 1995 Mice lacking progesterone receptor exhibit pleiotropic reproductive abnormalities. Genes and Development 9 2266-2278. (https://doi.org/10.1101/ gad.9.18.2266)

McGillivray SM, Thackray VG, Coss D \& Mellon PL 2007 Activin and glucocorticoids synergistically activate follicle-stimulating hormone beta-subunit gene expression in the immortalized LbetaT2 gonadotrope cell line. Endocrinology 148 762-773. (https://doi.org/ 10.1210/en.2006-0952)

Messager S, Chatzidaki EE, Ma D, Hendrick AG, Zahn D, Dixon J, Thresher RR, Malinge I, Lomet D, Carlton MB, et al. 2005 Kisspeptin directly stimulates gonadotropin-releasing hormone release via $\mathrm{G}$ protein-coupled receptor 54. PNAS 102 1761-1766. (https://doi. org/10.1073/pnas.0409330102)

Pickering AJ \& Fink G 1976 Priming effect of luteinizing hormone releasing factor: in-vitro and in-vivo evidence consistent with its https://joe.bioscientifica.com https://doi.org/10.1530/JOE-19-0013 (c) 2020 Society for Endocrinology Published by Bioscientifica Ltd.
Printed in Great Britain 
dependence upon protein and RNA synthesis. Journal of Endocrinology 69 373-379. (https://doi.org/10.1677/joe.0.0690373)

Roa J, Vigo E, Castellano JM, Gaytan F, Garcia-Galiano D, Navarro VM, Aguilar E, Dijcks FA, Ederveen AG, Pinilla L, et al. 2008a Folliclestimulating hormone responses to kisspeptin in the female rat at the preovulatory period: modulation by estrogen and progesterone receptors. Endocrinology 149 5783-5790. (https://doi.org/10.1210/ en.2008-0604)

Roa J, Vigo E, Castellano JM, Gaytan F, Navarro VM, Aguilar E, Dijcks FA, Ederveen AG, Pinilla L, van Noort PI, et al. 2008b Opposite roles of estrogen receptor (ER)-alpha and ERbeta in the modulation of luteinizing hormone responses to kisspeptin in the female rat: implications for the generation of the preovulatory surge. Endocrinology 149 1627-1637. (https://doi.org/10.1210/en.2007-1540)

Schauer C, Tong T, Petitjean H, Blum T, Peron S, Mai O, Schmitz F, Boehm U \& Leinders-Zufall T 2015 Hypothalamic gonadotropinreleasing hormone $(\mathrm{GnRH})$ receptor neurons fire in synchrony with the female reproductive cycle. Journal of Neurophysiology $\mathbf{1 1 4}$ 1008-1021. (https://doi.org/10.1152/jn.00357.2015)

Stephens SB, Tolson KP, Rouse Jr ML, Poling MC, Hashimoto-Partyka MK, Mellon PL \& Kauffman AS 2015 Absent progesterone signaling in kisspeptin neurons disrupts the LH surge and impairs fertility in female mice. Endocrinology 156 3091-3097. (https://doi.org/10.1210/ en.2015-1300)

Steyn FJ, Wan Y, Clarkson J, Veldhuis JD, Herbison AE \& Chen C 2013 Development of a methodology for and assessment of pulsatile luteinizing hormone secretion in juvenile and adult male mice. Endocrinology 154 4939-4945. (https://doi.org/10.1210/en.2013-1502)

Thackray VG \& Mellon PL 2008 Synergistic induction of folliclestimulating hormone beta-subunit gene expression by gonadal steroid hormone receptors and Smad proteins. Endocrinology 149 1091-1102. (https://doi.org/10.1210/en.2007-1498)

Thackray VG, McGillivray SM \& Mellon PL 2006 Androgens, progestins, and glucocorticoids induce follicle-stimulating hormone betasubunit gene expression at the level of the gonadotrope. Molecular Endocrinology 20 2062-2079. (https://doi.org/10.1210/me.2005-0316)

Turgeon JL \& Waring DW 1994 Activation of the progesterone receptor by the gonadotropin-releasing hormone self-priming signaling pathway. Molecular Endocrinology 8 860-869. (https://doi.org/10.1210/ mend.8.7.7984148)

Turgeon JL \& Waring DW 1999 Androgen modulation of luteinizing hormone secretion by female rat gonadotropes. Endocrinology 140 1767-1774. (https://doi.org/10.1210/endo.140.4.6642)
Turgeon JL \& Waring DW 2001 Luteinizing hormone secretion from wildtype and progesterone receptor knockout mouse anterior pituitary cells. Endocrinology 142 3108-3115. (https://doi.org/10.1210/ endo.142.7.8282

Turgeon MO, Silander TL, Doycheva D, Liao XH, Rigden M, Ongaro L, Zhou X, Joustra SD, Wit JM, Wade MG, et al. 2017 TRH action is impaired in pituitaries of male IGSF1-deficient mice. Endocrinology 158 815-830. (https://doi.org/10.1210/en.2016-1788)

Veldhuis J, Yang R, Roelfsema F \& Takahashi P 2016 Proinflammatory cytokine infusion attenuates LH's feedforward on testosterone secretion: modulation by age. Journal of Clinical Endocrinology and Metabolism 101 539-549. (https://doi.org/10.1210/ jc.2015-3611)

Waring DW \& Turgeon JL 1980 Luteinizing hormone-releasing hormoneinduced luteinizing hormone secretion in vitro: cyclic changes in responsiveness and self-priming. Endocrinology 106 1430-1436. (https://doi.org/10.1210/endo-106-5-1430)

Waring DW \& Turgeon JL 1992 A pathway for luteinizing hormone releasing-hormone self-potentiation: cross-talk with the progesterone receptor. Endocrinology 130 3275-3282. (https://doi.org/10.1210/ endo.130.6.1317780)

Wen S, Schwarz JR, Niculescu D, Dinu C, Bauer CK, Hirdes W \& Boehm U 2008 Functional characterization of genetically labeled gonadotropes. Endocrinology 149 2701-2711. (https://doi.org/ 10.1210/en.2007-1502)

Wen S, Ai W, Alim Z \& Boehm U 2010 Embryonic gonadotropinreleasing hormone signaling is necessary for maturation of the male reproductive axis. PNAS 107 16372-16377. (https://doi.org/10.1073/ pnas.1000423107)

Wen S, Gotze IN, Mai O, Schauer C, Leinders-Zufall T \& Boehm U 2011 Genetic identification of GnRH receptor neurons: a new model for studying neural circuits underlying reproductive physiology in the mouse brain. Endocrinology 152 1515-1526. (https://doi.org/10.1210/ en.2010-1208)

Wu S, Chen Y, Fajobi T, DiVall SA, Chang C, Yeh S \& Wolfe A 2014 Conditional knockout of the androgen receptor in gonadotropes reveals crucial roles for androgen in gonadotropin synthesis and surge in female mice. Molecular Endocrinology 28 1670-1681. (https://doi. org/10.1210/me.2014-1154)

Zhou X, Wang Y, Ongaro L, Boehm U, Kaartinen V, Mishina Y \& Bernard DJ 2016 Normal gonadotropin production and fertility in gonadotrope-specific Bmpr1a knockout mice. Journal of Endocrinology 229 331-341. (https://doi.org/10.1530/JOE-16-0053)

Received in final form 17 September 2019

Accepted 4 October 2019

Accepted Manuscript published online 4 October 2019 https://joe.bioscientifica.com https://doi.org/10.1530/JOE-19-0013 (c) 2020 Society for Endocrinology Published by Bioscientifica Ltd. Printed in Great Britain 